\title{
Tähelepanekuid ja mõtteid TLÜ artiklite kogumikku „Haridusmõte" lugedes
}

\author{
Edgar Krull ${ }^{\mathrm{a}}$ \\ ${ }^{a}$ Tartu Ülikool
}

Heidmets, M. (koost ja toim). (2020). Haridusmõte. Tallinn: TLÜ Kirjastus.

Raamat „Haridusmõte 2020“ annab põhjaliku ülevaate ja kokkuvõtte Tallinna Ülikooli ja tema eelkäijate saja-aastasest arengust ja saavutustest haridusmõtte ja õpetajakoolituse valdkonnas. 19 artiklist koosneva teose autorid on põhiliselt Tallinna Ülikooli õppejõud ja teadurid, aga ka nende koostööpartnerid väljaspool ülikooli. $550 \mathrm{lk}$ kogumiku koostaja ja toimetaja on prof Mati Heidmets. Artiklid jaotuvad kogumikus neljaks põhiteemaks: haridusmõtte kujunemine; probleemide kaardistamine ja uurimine haridusvaldkondades; pingeväljad haridusuuringutes ja psühholoogia lõimimisvõimalusi kasvatusteadustega; kooliuuenduse ja tulevikuhariduse käsitlused erinevates tahkudes, sealhulgas digitehnoloogia rakendamisena koolipraktikasse.

Kuivõrd hariduse valdkonnas pole sugugi haruldane, et käsitletavaid probleeme ja lahendusi nähakse sageli erinevas valguses, siis järgnevas artiklite tutvustuses ei piirdu ma vaid nende lühikirjeldustega, vaid osutan ka võimalikele alternatiivsetele käsitlustele, aga ka küsitavustele probleemide lahendamisel, seda muidugi oma vaatevinklist nähtuna.

\section{Haridusmõtte arengurajad}

Teose esimene osa „Haridusmõtte arengurajad“ hõlmab viit artiklit, mis haaravad haridusmõtte järjepidevuse käsitlusi, õppekavaarenduse traditsioonide kaardistamist, haridusmuudatusi oppetajate silme läbi, alternatiivpedagoogika arengut ja paradigmaatiliste muutuste võimalikkust haridusuuringutes.

Artiklis „Eesti kasvatusteadusliku mõtte järjepidevusest ja jätkuvusest“ keskenduvad Airi ja Reet Liimets Eesti haridusmõtte järjepidevuse analüüsile. Autorid näevad Eesti haridusalase mõtteloo kõige väärikamate esindajatena 20. sajandi algupoolel Johannes Käisi ja keskpaigas Heino Liimetsa. Põhikriteeriumideks nende eelistamisel teiste väljapaistvate pedagoogide, näiteks Peeter Põllu, Aleksander Elango, Inge Undi ees on tervikliku uurimisprogrammi ja oma koolkonna loomine. Sarnasusena Käisi ja Liimetsa teooriates toovad autorid esile lähtumise sotsiaalkultuurilisest kontekstist, kesksete tuummõistete (Käisil isetegevus ja Liimetsal elustiil) rõhutamises, kasvatusprotsessi 
eesmärkide mõistmises, kasvatava õpetuse olulisuse rõhutamises (didaktilise tegelikkuse nägemisena laiema kasvatustegevuse osana) ja õppetöö organisatsiooniliste vormide õppeaine sisust olulisemaks pidamises (lk 46-47).

Kuivõrd autorid rõhutavad, et kesksel kohal on haridusnähtuste (isetegevuse ja elustiili kui kontseptsioonide) käsitlemine süsteemse teooriana, siis lugejana eeldanuks veenvamat selgitust, milles süsteemsus seisneb. Kui selle keskne idee on kasvatava õpetuse kontseptsioon, mis pärineb Saksa kasvatuskeskse didaktika traditsioonist, siis oleks loogiline näha süsteemi selle kolme idee kooslusena: kasvatuse kontseptsioon, hariduse sisu teooria ning arusaam õpetamisest tähendusliku suhtena õpilase ja õppesisu vahel (vt Deng, 2013; Hopmann, 2007). Nii saaks Käisi ja Liimetsa uurimisprogramme analüüsida panusena nende kolme süsteemse idee teostamisse. Samuti võiks kaaluda uurimisprogrammide hindamist panusena mõne teise tervikliku (reform-) pedagoogilisse süsteemi komponentide ja institutsioonide arendamisse. Ka aitaks isetegevuse ja elutegevuse kui tuummõistete avamine kindla pedagoogilise süsteemi kui terviku valguses veenvamalt näha, milles ja kuidas avaldub järjepidevus ja jätkuvus. Nii või teisiti on artikli näol tegemist väärtusliku panusega Eesti haridusteadusliku mõtte ajaloo käsitlusse.

Artiklis „Eesti taasiseseisvumisjärgne õppekavaarendus euroopaliku didaktika ja anglo-ameerika curriculum'i risttuules" võtab Maria Erss vaatluse alla teema, mis on meid intrigeerinud taasiseseisvumisest peale. Teemaarenduses püüab ta avada ühelt poolt meie õppekavaalase mõtlemise teoreetiliste aluste kujunemise Mandri-Euroopa ja Anglo-Ameerika traditsioonidena ning teisalt meie oma õppekavaarendusega seostuvad probleemid. Eesti õppekavade analüüsimisel näeb autor keskse probleemina, kuidas neis nähakse õpetajate rolli ja autonoomiat. Artikli teoreetilises osas arutleb autor saksa didaktika osisena käibiva Lehrplan'i ja ameerikaliku curriculum'i traditsiooni erinevuste üle. Siin oleks oodanud selgemat sõnumit, mida autor võrdleb traditsioonidena.

Saksa didaktika traditsioon tähendab, nagu autor ka selgitab, kasvatava õpetuse keskset lähenemist pedagoogilise süsteemina, kus õpetajal on suur vabadus Lehrplan'ina edastatud sisu tõlgendamiseks, milleks oskus on talle kindlustatud unifitseeritud õpetajakoolitusega ja millega omakorda kindlustatakse sisendipõhine kontroll õpetamise kvaliteedi üle. Raskem on artiklist selgusele jõuda, mida tähendab curriculum-traditsioon, eriti kui seda iseloomustada vaid väljundipõhisusena vastandatult Saksa didaktika traditsioonile. Väljundipõhisel lähenemisel võib õpetaja autonoomia õppekava tõlgendamisel või isegi valikul olla piiritu, kui ta vaid kindlustab nõutud õpitulemuste saavutamise (vt nt Wermke ja Forsberg, 2016, lk 164). 
Eesti õppekavade vallas annab artikkel väärtusliku ülevaate arutlustest üldhariduskooli õppekava seadustamise, õppekavapoliitika joondumisest demokraatlikus maailmas valitsevatele tõekspidamistele, õpetaja autonoomiast arusaamade kujunemisest, üldpädevuste seostamisest ainekavadega ja tulevikuperspektiividest õppekavaarenduses.

Kolmas artikkel kannab pealkirja „Eesti haridusalased muutustealgatused kogenud õpetajate vaates: retoorika ja hariduspraktika", selle on kirjutanud Rain Mikser ja tema briti kolleeg Ivor Goodson. Artikkel annab ülevaate varasematest uuringutest haridusmuutuste kohta ja tutvustab Eestis tehtud uuringut õpetajate isiklike ja ametialaste elulookirjelduste väljaselgitamiseks. Teoreetilises osa toetuvad autorid David Tyacki (1991) üldistustele haridusuuenduste seaduspärasuste avamisel, samas illustreerides neid meie kogenud õpetajate arvamusavaldustega. Selgelt ilmnevad haridusuuenduste kaks probleemi: juba käibel olnud ideede taasavastamine ja uuenduste tõrjumine. Seejuures toovad autorid esile Tyacki olulise tähelepaneku, et iga muudatusettepanekute laine negatiivseks nähuks on uute ametnike lisandumine, kes peavad oma ametikoha õigustamiseks näitama algatatud uuendusi eriti olulisena ja põhimõtteliselt uuena. Tagajärjeks on ametnikkonna suuruse ja mõju kasv. Artikli lõpuosas toovad autorid välja nn uute õpikäsituste näidetena rõhuasetuse töökasvatusel, koostööl, aktiivõppe vastandamise traditsioonilisega.

Kuigi artikkel hõlmab teemat väga laialt, oleks haare veelgi laiem, kui uuenduste seaduspärasuste käsitlemisel pälvinuks enam tähelepanu massikommunikatsiooni rattaleiutuslik mõju. Nii mõnigi kord ületab uuendajate kõvahäälsus nende kompetentsuse. Probleemi olemuse on hästi tabanud Jaak Aaviksoo, osutades, et „... oleme demokraatlikul moel andmas kõigile võimalust kuulutada oma tõde, lootuses, et igaühe isiklik tarkus võimaldab tõde ja valet paremini eristada, kui me seda ühiselt suudaks“, ning kahelnud, „... kas see ka tegelikult igaühele meist jõukohane on" (Aaviksoo, 2017). Väheusutav, et kommunikatsioonivabadusest tulenev kontrollimatu infotulv ei mõjuta, kuidas õpetajad, eriti aga eakad ja kogenud õpetajad, tajuvad muudatusalgatusi hariduses, ja see vääriks eraldi uurimist.

Neljanda artikli „Alternatiivpedagoogika arengutee Eesti haridus- ja kasvatustegelikkuses" autor on Tiiu Kuurme. Osaliselt on see autobiograafiline ja emotsionaalne ülevaade meil puhkenud alternatiivpedagoogiliste ideede levitamisest ja juurdumisest taasiseseisvumisel. Artikkel algab ülevaatega alternatiiv- ja reformpedagoogiliste ideede olemusest ja levikust maailmas. Seejärel käsitleb autor alternatiivpedagoogiliste ideede levikut ja aktsepteerimist eesti pedagoogide seas. Käsitlus lõpeb põhjaliku ülevaatega Eestis tegutsevatest alternatiivpedagoogilistest koolidest ja nende eripärast. Mõneti problemaatiline tundub teema arenduses olevat alternatiivpedagoogiliste käsituste liiga jäik 
eristamine nn konventsionaalsetest käsitustest. See võib endas kätkeda ohtu, et lugejal on alternatiivseks nimetavas lahenduses või idees raske märgata ammu aktsepteeritut ja endastmõistetavat näiteks haridusfilosoofiliste suundumuste, óppekava tüüpide, pedagoogilis-psühholoogilise teadmise tähenduses. Ka on küsitav erakoolide samastamine alternatiivkoolidega. Kuid kumbki tähelepanek ei vähenda artikli väärtust põhjaliku ja mõtlema paneva ülevaatena alternatiivpedagoogilisest mõtlemisest ja praktikast Eestis.

Esimese osa viimane artikkel „Paradigmavahetuse võimalikkusest kasvatusteadustes" on lühendatud versioon Viive-Riina Ruusi artiklist, mis ilmus 2018. aastal Akadeemias. Tegelikult plaanis meie seast lahkunud Viive-Riina Ruus raamatusse artiklit, mis olnuks edasiarendus Akadeemias avaldatud analüüsist.

Sarnaselt Akadeemia artikli käsitusega seab ka lühiversioon kesksele kohale Kantist (1724-1804) peale teada oleva asja iseeneses ja asja meie jaoks dilemma. Nähtusi, mis pole lõpuni tunnetatavad või kus kellelgi pole valemit, mis tooks esile kogu tõe (vt Kagan, 2017), nimetab ta nurjatud probleemideks. Need on eriti omased haridusvaldkonnale. Lahendust nurjatud probleemidele näeb autor komplekssüsteemide teooria rakendusena. Artikkel annabki ulatusliku ülevaate selle teooria rakendamise võimalustest sotsiaalteadustes. Keskseks ehk tuummõisteks kasvatuse ja hariduse valdkonnas on õppimine nii isiklikul kui ka institutsionaalsel tasandil. Eriti huvitav on artikli ülevaade eeldustest, mis lubaksid kasutada komplekssüsteemide teooriale omast metoodikat Eesti olukorra ja probleemide analüüsiks. Ka on igati silmaringi laiendav järgnev ülevaade arengutest maailmas, mis viitavad autori hinnangul eesseivale paradigmamuutusele, kus distsiplinaarsus asendub probleemide nägemisega komplekssüsteemidena ja kus keskne tuummõiste on õppimine.

\section{Alusharidusest elukestva õppimiseni}

Raamatu teine osa pealkirjaga „Alusharidusest elukestva õppimiseni“ koosneb sarnaselt esimese osaga viiest artiklist. Artiklite temaatika hõlmab arengut ja probleeme alushariduses, õpetajakoolituses, kutsehariduses, andragoogikas ja noorsootöös.

Esimeses artiklis „Alusharidus loob vundamendi“ annavad Tiia Õun, Maire Tuul ja Aino Ugaste ülevaate Eesti alushariduse kui institutsiooni ajaloolisest kujunemisest ja selle olemusest Euroopa kontekstis. Eraldi probleemidena käsitlevad autorid „Hea alguse“ programmi mõju lapsekesksuse kujunemisele lasteaedades pärast taasiseseisvumist, õppekavade kujunemist ja rakendamisest alushariduses ning lasteaias töötava pedagoogilise personali rolli ja ülesannete ümbermõtestamist. Artikli ülevaade taasiseseisvumisjärgsete 1999. 
ja 2008. aasta riiklike õppekavade kujunemisest ja olemusest võiks olla tänuväärseks lähtematerjaliks kolmanda põlvkonna õppekavade koostamisele, kui kaks projekti (valminud 2019) on juba tagasi lükatud ja kolmas koostamisel. Uudse probleemina on artiklis tõstatatud digitehnoloogia roll laste arengus. Kriitiliselt poolelt vaadatuna tundub artiklis mõneti üle lihtsustatuna nõukoguliku kollektiivikeskse kasvatuse vastandamine lapsekesksele. Siin oodanuks enam tähelepanu sellele, et ka lapsekesksus tähendab elama õppimist erinevate kogukondade liikmena. Ka tundub, et käsitlus õpikäsitusest oleks selgem, kui see oleks avatud õppimispsühholoogia termineis. Kuid need kaks kriitilist tähelepanekut ei vähenda artikli väärtust tervikuna alushariduse mineviku ja tuleviku avamisel ja mõistmisel.

Teise artikli „Õpetajakutsest ja õpetajakoolitusest Tallinna Ülikoolis“ autorid on Kadi Georg ja Katrin Poom-Valickis. Artikkel on sümboolse tähendusega, sest ilmumise ajaks on möödunud sada aastat õpetajahariduse andmisest Tallinna Ülikoolis. Põhiteemadena analüüsivad autorid selles Eesti õpetajaskonda, õpetajakutse mainet, õpetajakoolituse arengut ja selle tulevikuväljavaateid.

Eesti õpetajaskonna iseloomustamisel tõstatavad autorid esile probleemidena selle kesise pealekasvu, vananemise ja madala ühiskondliku prestiiži. Eriti halb on olukord matemaatika ja loodusainete õpetajate pealekasvuga. Õpetajakutse mainet mõjustavate faktoritena toovad autorid esile madala palgataseme, suure töökoormuse, madala staatuse ja kutseala jätkuva feminiseerumise. Kirjeldatud on ka initsiatiive õpetajameti populariseerimiseks.

Iseloomuliku arengujoonena õpetajakoolituses toovad autorid esile, et lisaks ainealastele teadmistele on üha enam hakatud väärtustama „... oskusi üldpädevuste kujundamiseks, õpioskuste ja eneseregulatsiooni võimekuse arendamiseks, valmisolekut elukestvaks õppeks ning toimetulekut uudsete ning kiirelt muutuvate olukordadega" (lk 228). Samuti on suurenenud pedagoogilise praktika maht ja suurenenud tähelepanu praktika seostamiseks teoreetiliste õpingutega. Tulevikutaotlusteks on valdkondlike õppekavade ja õppekorralduse kohandamine ajanõuetele ning kutseaasta tugiprogrammi ja täienduskoolituse sisu uuendamine.

Artikkel oleks olnud veelgi veenvam, kui selles oleks selgemini välja öeldud, mis on autorite käsituses õpetajakoolituse sisu lähtealuseks, kas õpetaja kutsestandard (vt lk 228) või valdkondlikud teadusuuringud. Tervikuna on see aga värrtuslik ülevaade õpetajakoolitusest TLÜs ja õpetajaskonna seisundist.

Kolmanda artikli „Kutsehariduse sotsiaalne ökoloogia“ on kirjutanud Krista Loogma. Artikkel algab kutsehariduse traditsioonide tutvustamisega saksakeelsetes riikides ja meie probleemide avamisega nähtuna sotsiaalses keskkonnas. Järgneb ajalooline ülevaade, kuidas kutseharidus on arenenud 
nõukogulikult süsteemilt EL kutsehariduse raamistikku. Nõukogude kutsehariduse süsteemi käsituses väärinuks selle plaanimajanduslikule iseloomule osutamisele lisaks pöörata rohkem tähelepanu ka sunniviisilisusele kutsekoolidesse suunamisel, mida rakendades püüdsid võimud leevendada oskustööliste defitsiiti. Sellest tingitud kutsehariduse madal prestiiž on senini visa taanduma. Probleemina on see aimatav ka alajaotuses „Kutsehariduse nõiaring".

Hea ülevaate taasiseseisvumisele järgnenud arengust leiab artikli alajaotustest „Kutsehariduse reform“ ja „Kutsehariduse euroopastumine“. Edasi jätkab autor kutseõppe problemaatika avamist, süüvides muutustesse kutseõpetaja rollis. Neid näeb autor eelkõige muutustena kvalifikatsiooninõuetes ja muutunud õpilaskonnas. Erinevuste selgitamine õpetajate kutseidentiteedis tingituna kutseõpetajate puhul õpilaskonnas toimunud muutustest ja üldhariduskooli õpetajate puhul neoliberaalsest orientatsioonist väljundipõhisusele pole esitatud kujul päris veenev ja vajaks paremat lahtikirjutamist. Erinevalt traditsioonilisest lähenemisest, kus artikkel lõpeb kokkuvõttega käsitatust, on tutvustatavas artiklis asendatud see ülevaatega CEDEFOPi kutsehariduse kolmest arengustsenaariumist. Ilmselt aitabki see lahendus näha kogu artiklis esitatut paremini vaatega tulevikku kui traditsiooniline kokkuvõte.

Neljanda artikli „Täiskasvanuharidus ja elukestev õppimine“ autor on Larissa Jõgi. Artikkel algab probleemide avamisega täiskasvanuhariduse mõiste defineerimisel. Järgneb detailne ülevaade täiskasvanuhariduse kujunemisest Eestis. Kujunemisloo käsitlus algab Eestimaa Rahvahariduse Seltsi asutamisest 1906. aastal ja kajastab edasist arengut täiskasvanuhariduses 2020. aastani. Täiskasvanuõppe olemuse avamiseks esitatud näited hõlmavad arusaamu õppimisest, õppimise võimestavast toimest, tunnetatud vajadusest õppida ja elukestvast õppimisest. Õppimise käsitlemisel ootaks siiski selgemat eristust loomuliku, tahes-tahtmata toimuva elukestva õppimise ja täiskasvanukoolituses-hariduses või täiendusõppes toimuva õppimise vahel. Artiklist leiab ka hea ülevaate andragoogika kui õppesuuna kujunemisest Tallinna Ülikoolis, uurimissuundadest ja rahvusvahelisest koostööst.

Viienda artikli „Noorsootöö kujunemisloost kaasaegse noorsootöö mõistmiseni“ autorid on Ilona-Evelyn Rannala ja Heili Griffith. Artikli sissejuhatus annab hea ettekujutuse noorsootööst kui raskesti määratletavast institutsioonist nii selle toimumise keskkonna kui ka noorsootöötajate ametinimetuste varieeruvuse tähenduses. Järgneb ülevaade organiseeritud noorsootöö kujunemisest Euroopas, toetudes põhiliselt Filip Coussée (2010) noorsootöö ajaloo käsitusele, ning seejärel ülevaade Eesti noorsootöö ja seda reguleeriva seadustiku kujunemise ajaloost. Edasi keskenduvad autorid noorsootöö 
haridusideoloogilistele taotlustele, seejuures toetudes ka Paulo Freire vabastava hariduse kontseptsioonile.

Võimalik, et orienteerumine noorsootöö ideoloogilistes alustes olnuks lugejale hõlpsam, kui need oleksid avatud põhiliste haridusfilosoofiliste orientatsioonidena. Sama võib öelda noorsootöö eesmärkides orienteerumise kohta, kus võimalused on ühelt poolt noorte ettevalmistus edukaks täiskasvanueluks ja olemasolevas ühiskonnas hästi toimivateks kodanikeks (kui lapsepõlvest täiskasvanuikka ülemineku hõlbustamine) ja teiselt poolt foorumi pakkumine, kus noored saaksid „... enda vajaduste ja tulevikusoovide üle arutada ning koos muuta oma sotsiaalset olukorda“ (lk 300).

Ka leiab artiklist huvitava ülevaate noorsootöö spetsialistide ettevalmistuse põhimõtete ja eesmärkide erinevustest, jaotades riigid lähenemiste sarnasuse alusel kolme rühma, ning polemiseeriva arutluse noorsootöö spetsialistide ettevalmistamise tulevikust.

\section{Pinged ja valikud}

Raamatu kolmas osa kannab pealkirja „Pinged ja valikud“. Selle viis artiklit hõlmavad selliseid poleemilisi teemasid nagu õpilaskesksus, üldpädevuste keskne õpe, alternatiivne lähenemine õppimise ja õpetamise käsitamisel, kooli valik ning digisõltuvus ja -ärksus.

Esimeses artiklis „Õppijakeskne lähenemine õpetamisele“ võtab Inge Timoštšuk vaatluse alla keerulise ja vastuolulise teema. Tõdedes, et õppijakesksus on raskesti üheselt defineeritav, piiritleb ja konkretiseerib autor selle õpilase autonoomsuse toetamise ja õpetamise struktureerimisega eri metoodilistes süsteemides, milleks on uurimuslik, probleem- ja projektõpe. Järgnev arutlus õppija autonoomsusest ja õpetamise struktureerimisest aitab kindlasti süüvida õpilaskesksuse avaldumise eripäradesse, kuid jääb liiga üldiseks, otsustamaks nende põhimõtete rakendamise piiride üle. Ilmselt tajudes probleemi, piirdub autor õpilaste autonoomia ja tegevuse struktureerimise võimaluste analüüsil kolme nimetatud õppemetoodilise süsteemiga. Kuigi autor möönab, et probleemõpe on sarnane uurimusliku õppega ja uurimuslik õpe projektõppega, oodanuks lugejana nende õppemetoodiliste süsteemide sarnasuste ja erinevuste selgemat väljatoomist.

Kui mõelda artiklis tõstatatud temaatika edasiarendamisele, võiks lisaks õppijakesksuse rakendamisele vahetus õppetöös õpilaste individuaalse eripäraga arvestamisena kaaluda ka õpilaskesksuse käsitlemist üldisematest hariduseesmärkidest lähtuvalt.

Eve Kikase artikkel „Üldpädevuste esiletõus. Psühholoogia varjatud sissetung kasvatusteadustesse“ käsitleb, nagu pealkiri juba rõhutab, üldpädevuste 
kui õppe-eesmärkide temaatikat psühholoogia positsioonidelt. Kuigi idee õppeaineteülestest õpiväljunditest tuleneb tõenäoliselt Saksa kasvatava õpetuse kontseptsioonist, mille kohaselt peab õppeainete sisu olema nii konstrueeritud, et see sisaldaks kasvatuslikku substantsi (Klafki, 2000), rakendus see algul Herbartilt pärit idee õppeaineüleste õppe-kasvatuseesmärkide püstitamisena üldhariduses alles poolteist sajandit hiljem.

Üldpädevuste kujunemise avamiseks psühholoogia positsioonilt võtab autor vaatluse alla nende formeerumise aluseks olevad spetsiifilised õppimisprotsessid. Psühholoogiliste protsesside detailne avamine aitab paremini süüvida pädevuste kujunemise seaduspärasustesse, kuid võib kätkeda ka ohtu, et psühholoogias vähem kodus olev lugeja hakkab nägema pädevuste kujunemist muust õppimisest eristuvana. Kuid järgnev arutlus aineõpingute ja pädevuste kujunemise seostest ja näited tüüpilistest väärarusaamadest õppetöös ei anna selleks alust. Artikkel on üheks tõendiks, et unistus õppeainete kasvatuslikust substantsist on realiseerumas pädevuste kujundamise ja hindamise õpiväljundina.

Kolmas artikkel „Õppimise ja õpetamise olemusest ning (eri)pedagoogi óppekava ülesehitusest" Aaro Toomelalt käsitleb hariduse probleeme psühholoogi vaatevinklist. Artikkel algab põhjaliku ülevaatega autori teadusmetodoloogilistest arusaamadest, mis on aluseks edasisele käsitusele. Järgmisena avab autor neist lähtuvalt õppimise ja õpetamise olemuse. Sissejuhatusena polemiseerib ta õpetamise eesmärgi üle riiklikes õppekavades ning avab siis oma käsitusest lähtuvalt psüühika olemuse ja selle komponendid (indiviidi ja tema keskkonna tähenduses). Järgneb õppimise olemuse avamine psüühika arengu kontekstis ning seejärel arutluste järeldustena definitsioonid õppimise ja õpetamise kohta.

Et autori käsituse isikupära tuleks veenvamalt esile, oodanuks, et artiklis oleks selgemini välja toodud, milles seisnevad põhierinevused tunnetusprotsesside ja õppimise olemuse mõistmisel peavoolu käsitustest psühholoogia ja pedagoogilise psühholoogia õpikutes (vt nt Gleitman jt, 2014; Eggen ja Kauchak, 2016) või õpetamise käsitamisel õppimiseks tingimuste loomisena (vt nt Gagné, 1985).

Aaro Toomela artikli kõige huvipakkuvam osa on isiksuse, tunnetusprotsesside ja õppimise käsitustest lähtuvate õpetajakoolituse õppekavaprojektide väljapakkumine. Senisele õpetajakoolituse kursuste sisule heidab autor ette staatilisust, et neis kajastuv arengupsühholoogia ei ava, kuidas toimub areng ühest psüühilise arengu seisundist teise, ning et kasutatavad pedagoogilise psühholoogia õpikud on ehitatud üles, lähtudes psühholoogia valdkondade loogikast ja mitte pedagoogika vajadustest (lk 373). Suhet üldpedagoogilise ja eripedagoogise ettevalmistuse vahel näeb autor sarnasena üldarstiteaduse ja 
eriarstiõppega, kus alguses kõik õpivad arstiks ja siis omandavavad kitsama eriala. Artiklis pakutud meetmed psüühika ja selle komponentide pedagoogiliseks käsitlemiseks õpetajakoolituses, millest senistes pedagoogika ja pedagoogilise psühholoogia kursustes on autori hinnangul vajaka jäänud, peaksid pälvima kõige tõsisemat tähelepanu kolleegidelt, kes vastutavad õpetajakoolituse õppekavade eest.

Neljas artikkel „Digisõltuvus ja digiärksus“ pärineb Riin Seema ja Kristi Vinter-Nemvaltsi sulest. Artiklis käsitletakse globaalselt intrigeerivaid teemasid - digi- ja interneti- (sisu valiku ja tarbimise) pädevust ehk autorite sõnadega digikäitumist ja digisõltuvust (lk 393). Artikli teemaarenduses on kaks põhilist liini: esiteks digisõltuvuse olemus, selle tekkimise põhjused, avaldumine, mõju ja ennetamine ning teiseks digiärksus toimetulekustrateegiana ja digiärksuse õpetamine. Kuigi digisõltuvuse peamiste põhjustena on korrektne nimetada uudsust ja ühelt tegevuselt teisele pidevat ümberlülitumist, mis tekitavad ajus mõnutunde, vajaks nende olemus enam lahti seletamist. Samas, digisõltuvuse üheks tunnuseks ajataju kadumise pidamine on digimeedia (interneti ja sotsiaalmeedia) tarbimisel igati veenev. Artikkel annab hea ülevaade digisõltuvuse mõjust õpilaste arengule.

Digisõltuvusega toimetuleku strateegiana näevad autorid digiärksust, mille põhimehhanismiks on eneseregulatsioonivõime. Et metakognitsioon ja eneseregulatsioon ei ole lastele kaasasündinud võimekused, vaid kujunevad järk-järgult õppides, siis kehtib see ka digiärksuse kujunemise kohta. Autorid toovad näiteks Ameerika Pediaatrite Assotsiatsiooni soovitused digipädevuse kujundamiseks eri vanuseastmetel. Need ulatuvad ekraanimeedia kasutamise vältimise soovitusest (vanuses $0-18$ kuud) kuni iseseisva eneseregulatsioonini jõudmiseni 11-12aastaste laste puhul. Üsna huvitav on ka artikli käsitlus digisõltuvuse ennetamisest ning digiärksuse õppimisest ja õpetamisest.

Kolmanda osa viimase artikli „Koolivalik, selle korraldamine ja sotsiaalne mõju“ autorid on Triin Lauri ja Kaire Põder. Artikkel annab põhjaliku ülevaate eri riikide koolivalikupoliitikast. Sellele järgnevad järk-järgult kitsenevalt arutlused esiteks perekondliku koolivaliku üle, siis Eesti praktika üle ja seejärel koolivaliku korraldusest Tallinnas. Koolivaliku poliitika suhtes jõuavad autorid järeldusele, et selle olemust ja tulemit mõjutavad perede koolivalikusse kaasatuse määr, selektiivne vastuvõtt õppimisvalmiduse järgi, erakoolide osakaal haridussüsteemis ja koolide autonoomia (lk 425).

Artikli käsitlus toetub ulatuslikult statistilistele andmetele, millest info ammutamine võib aga osutuda lugejale pingutust nõudvaks, sest sageli jääb selgusetuks, millist skaalat on kasutatud või millistes ühikutes on arvandmed väljendatud. Samas on teksti loetavus hea. Koolide tõhususe hindamise käsitus oleks olnud veelgi veenvam ja mitmekülgsem, kui õpiväljunditepõhise 
hindamise kõrval oleks kaalutud ka hindamist juurdekasvuna (lisandväärtusena) õpitulemustes (vt nt Must, 2016 ja 2019). Kuid mainitu ei vähenda artikli väärtust põhjaliku ülevaatena koolivaliku keerulisest temaatikast. Võib vaid nõustuda autoritega, et tundes „...poliitikaid ja korraldusi, mis taastoodavad ebavõrdsust ja suurendavad ühiskondlikke lõhesid..." (lk 440), saame neid vältida ja koolivaliku poliitikat tõhustada.

\section{Tulevikuvaated}

Artiklite kogumiku neljas osa „Tulevikuvaated“ koosneb neljast artiklist, mis keskenduvad kooliuuendusele, digitehnoloogiale muutunud õpikäsituste toetamiseks, teadmiste ülekandele haridusuuenduse võtmena ja tulevikukooli väljavaadetele.

Esimese artikli „Kooliuuendus: välised mõjurid ja ühiskondlik taust“ autorid on Eve Eisenschmidt ning „Haridusmõtte“ koostaja ja toimetaja Mati Heidmets. Autorid alustavad oma käsitlust kooliuuendust suunavate tegurite, rahvusvaheliste organisatsioonide haridusvisioonide ja haridusele töömaailma muutustest tulenevate ootuste analüüsist. Töömaailma muutuvatest ootustest toob artikkel välja, et töötajatelt eeldatakse laiemat erialaoskust, valmisolekut paindlikuks töösuhteks ja töökorralduseks, võimet oma tööd mõtestada, valmisolekut individuaalseks ja korporatiivseks vastutuseks ning võimet lõimida tööd ja eraelu. Esiplaanile tõusevad hariduses terviklikkuseagentsuse-vastutuse teemad. Keskset rolli selliste kompetentside kujunemisel mängib sisemine motivatsioon. Selle kujunemist ja toimimist avavad autorid isemääramise ja võimestumise teooriate valguses. Isemääramisteooriast tõukuvalt näevad autorid kooliuuenduslikke suundumusi õpilaste ettevalmistusena kolme põhivajaduse - autonoomia, kompetentsuse ja kuuluvuse tarvete rahuldamises kooskõlas arenguga ühiskonnas ja töömaailmas. Võimestumise teooria aga eeldab hariduse eesmärkidena õppuri liikumist suurema iseseisvuse ning välise sõltuvuse vähenemise suunas. Huvipakkuvad on ka autorite kokkuvõtvad mõtteavaldused kooliuuenduslike ideede rakendamise, koolide mitmekesistumise ja ühisosa nägemise kohta. Artiklis käsitletu ärgitab jätkuna küsima, kuivõrd kajastuvad kooliuuenduslikud, sealhulgas 20. sajandi alguse reformpedagoogilised ideed juba riiklikes õppekavades ning kaasaegsetes pedagoogika, pedagoogilise psühholoogia, õppekavateooria jt kursustes (õpikutes) ja kui ei, siis mis takistab neid kajastamast.

Teine artikkel „Õppimine ja õpetamine tehnoloogiarikkas keskkonnas“ on Kairit Tammetsalt ja Kaire Kollomilt. Artikkel algab ülevaatega digitehnoloogiliste vahendite rakendamispraktikast koolides, toetudes põhiliselt Hariduse Infotehnoloogia Sihtasutuse tellitud uuringule digioskuste 
õpetamisest üldhariduskoolides ja lasteaedades. Järgnevad arutlused digitaalse õppevara kasutamisvõimalustest üldisemas tähenduses ja ülevaade DigiÕppeVaramu projektiga üle 6000 ülesandepõhise digitaalse õppematerjali kättesaadavaks tegemisest (E-koolikoti vahendusel) õpetajatele ja gümnaasiumiõpilastele.

Materjalide koostamisel, nagu selgitavad autorid, järgiti ülesandekeskse õppedisaini mudelit ja toetuti õpetamise põhiprintsiipidele ning katsetega selgitati välja nende kasutamismustrid. Viimased on eriti huvipakkuvad digiõppevara kasutamisvõimaluste avamisel. Edasi tõdevad artikli autorid, et digivahendite kasutamisega kaasneb (või pigem toimub teadlik) andmete talletamine, mida saab kasutada õppetöö tagasisidestamiseks. See teostub ópianalüütika rakendamisena, mille võimalusi käsitlevad autorid eraldi ülevaadetena õppimise ja õpetamise toetamise kohta.

Siiski, võimalused ideede vahetuseks ja koostööks haridustehnoloogia ja üldpedagoogika vahel selles informatiivses ja innovaatilises artiklis oleksid veelgi suuremad, kui õpetamise põhiprintsiipide tuletamisel ja õpianalüütika rakendamise võimaluste avamisel oleks artiklis enam toetutud mõnele autoriteetsemale tunnetus- ja õppimisprotsesside käsitusele üldpedgoogikas või pedagoogilises psühholoogias.

Kolmandas artiklis „Tehnoloogiliste uuenduste tee klassiruumi: kooli ja ülikooli koostöömudelid“ võtavad Janika Leoste, Kairit Tammets ja Tobias Ley kooliuuenduse vaatluse alla laiemas tähenduses kui digitehnoloogia rakendamise praktika eespool tutvustatud Tammetsa ja Kollomi artiklis. Keskne teema on digilahendustele toetuvate haridusuuenduste juurutamine rakendades haridusuuenduste partnerlusmudelit (HUP). Autorid alustavad fundamentaaltasandilt, toetudes nende endi loodud teadmiste omaksvõtu mudelile. Mudelist omakorda tuletavad nad teadmiste kujunemise, toetamise ja omaksvõtu praktikad ning seostavad nendega ülikooli ja kooli partnerlusvormid.

Artikli põhiosa keskendubki haridusuuenduste rakendumisele koostööna ülikooli ja kooli vahel jaotatuna impulsside ja ideede, koosloome ja katsetamise ning juurutamise ja leviku etappideks. Uute lähenemiste katsetamine toimub partnerkoolides õpetajate innovatsioonilabori (ÕIL) raames. Uuenduste mõju hindamiseks töötab ülikool välja õpianalüütika tööriistakasti. Tööriistakasti instrumentide katsetamine ja hindamine toimub TLÜ juurde asutatud tehnoloogia toetatud õppimise ja õpetamise uurimise laboris. Oma uuendusmetoodika illustreerimiseks toovad autorid näited neljast koosloome projektist: robotmatemaatika, uurimuslik ja projektõpe värkvõrgu abil, projektõpe läbi loodusainete integreerimise mobiilse tehnoloogiaga ning mõtestatud matemaatika ja digitaalne õppekava. Esimene neist on arengujärgult kolmandas ja ülejäänud kolm teises etapis. 
Neljas artikkel, Eve Eisenschmidti, Kätlin Vanari ja Kairit Tammetsa kirjutatud „Tulevikukool: Eesti kooliuuenduse praktikast" käsitleb kooliuuenduse teemat veelgi laiemalt. Artikli sissejuhatavas osas võtavadki autorid kokku, et „valdavalt on senine kooliuuenduslik praktika, nii rahvusvaheliselt kui ka Eestis, suunatud koolielu üksikutele aspektidele...“ ja „...üldjuhul muutused on projektipõhised, seetõttu sageli ka ajutised“ (lk 511-512).

Oma teemaarenduses toetub artikkel TLÜ haridusuuenduse keskuses loodud tulevikukooli mudeli koolikultuuri aluspõhimõtetest tuletatud tegevusvaldkondadele, milleks on eestvedamine, koosloome ja tõendipõhisus. Konkreetse rakendusena tutvustavad autorid 2017. aastal käivitatud tulevikukooli programmi, milles on osalenud üheksa kooli. Programmi iseloomustavad autorid muutuste juhtimise aluspõhimõtetena, mis näivad tulenevat mainitud tegevusvaldkondadest, ning viimastest tulenevate programmi tegevuste ja nende etappidena. Artikkel lõpeb senisest praktikast tulenevate järelduste ja koolikultuuri muutmise mudeli väljapakkumisega. Siiski, kirjeldatud kooliuuenduslikud initsiatiivid oleksid veenvamad, kui esile tõstetud kooliuuenduse kolmest tegevusvaldkonnast pälviks enam tähelepanu tõendipõhisus nii programmi sees kui ka väljaspool seda. Kuid see soovituslik mõtteavaldus ei vähenda kuidagi artikli väärtust haridusuuendusliku visiooni ja kontseptsioonina.

\section{Kasutatud kirjandus}

Aaviksoo, J. (2017). Kui tõde hääletatakse. Postimees, 11.02.17.

Coussée, F. (2010). The saint, the poet, the lord and the cardinal. Learning from youth work's history. Coyote. Youth Work, Training, Research \& Policy, 15(2), $10-15$.

Deng, Z. (2013). On Developing Chinese Didactics: A Perspective from the German Didaktik Tradition. Frontiers of Education in China, 8(4), 559-575. https://doi.org/10.1007/BF03396991

Eggen, P., \& Kauchak D. (2016). Educational psychology: windows on classrooms (10th ed.) Boston: Pearson.

Gagné, R. M. (1985). The conditions of learning (4th ed.). New York: Holt, Rinehart \& Winston.

Gleitman, H., Gross, J., \& Reisberg, D. (2014). Psühholoogia. Tartu: Hermes.

Hopmann, S. (2007). Restrained teaching: The common cores of Didaktik. European Educational Research Journal, 6(2), 109-124.

https://doi.org/10.2304/eerj.2007.6.2.109

Kagan, J. (2017). Kolm kultuuri: Loodusteadused, sotsiaalteadused, ja humanitaarteadused 21. sajandil \& Snow, C. P. (2017). Kaks kultuuri ja teadusrevolutsioon. Tartu: Tartu Ülikooli Kirjastus. 
Klafki, W. (2000). Didaktik analysis as the core of preparation. In I. Westbury, S. Hopmann \& K. Riquarts (Eds.), Teaching as a reflective practice: The German Didaktik tradition (pp. 139-159). Mahwah, NJ: Erlbaum.

Must, O. (2016). Kas Eesti gümnaasiumid erinevad üksteisest oma õppetöö kvaliteedilt? Ettekanne välishindamise aastakonverentsil „Teel õppijakeskse hariduse poole“. Aadressilt https://www.hm.ee/sites/default/files/olev_must.pdf.

Must, O. (2019). Mainekas kool ei ole tingimata parem kool. Postimees, 26. märts 2019.

Tyack, D. (1991) Public school reform: policy talk and institutional practice. American Journal of Education, 100(1), 1-19. https://doi.org/10.1086/444002

Wermke, W., \& Forsberg, E. (2016). The changing nature of autonomy: Transformations of the late Swedish teaching profession. Scandinavian Journal of Educational Research, 61(2), 155-168. https://doi.org/10.1080/00313831.2015.1119727 